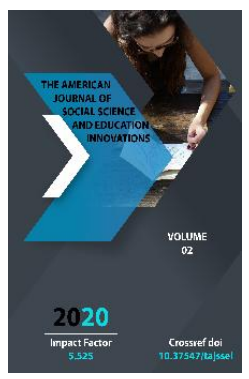

\title{
Ancient Uzbek Tribes And Clans Inhabiting In Central Asia
}

\author{
Aziza Khasanovna Aripova \\ PhD on Philology, Associate Professor, Specialized Branch Of Tashkent State University of \\ Law, Uzbekistan
}

Journal Website:

http://usajournalshub.c

om/index,php/tajssei

Copyright: Original

content from this work

may be used under the

terms of the creative

commons attributes

4.0 licence.

\section{ABSTRACT}

Soon afterward humankind became conscious of his social importance, heinitiated to comprehend the language's great benefits, the aspiration to make certain that through the tribes lived in the past, it is attainable to determine the historical roots of the language and to find out what is beyond the reach. Despite of the fear of ignorance, doubt and mistakes, diverse human communities began to study their similarities and differences, because of many reasons, including ethnic, tribal, pedigree, climatic, physiological, linguistic and cultural properties, ending with communicative, competently dialectical skills.

The antiquity of the Uzbek language is more outstanding when its appearance and development is considered in closely connection with the history of the formation and development of the native people. Without taking into account the historical laws of tribal and clan estates during the development of the Uzbek language, it is impossible to understand its distinct features, the totality of historically determined changes that have occurred not only in vocabulary, but also in the phonetic system, as well as partially in the grammatical structure of the Uzbek language. Therefore, the study of the Uzbek language at different phases of the historical development of the Uzbek people; the identification of its specific features in the grammatical and lexical structures; the establishment of the relationship between the written language and active spoken language, presented in the form of numerous subdialects and dialects; the definition of thedialect assist to a more correct comprehension of the history of the Uzbek language as a whole.

\section{KEYWORDS}

Barlas, durmans, kangli, intensive group interaction, communication, formation and development of communicative and social competence, integration, productive cooperation, mangits, ethnic composition of Uzbeks, Karakalpaks, resettlement, territory of Uzbekistan, cultural influence of local Turkic people. 


\section{INTRODUCTION}

Interethnic, interfaith, intercultural and interlanguage tolerance is a historical aspect of the Uzbek people. The language formation process of any nation is directly associated with the history of origin and formation of native speakers of that language. Therefore, the study of the ethnic composition of the Uzbek language is unachievable without the joint efforts of historians, ethnographers, linguists, archaeologists and representatives of other related sciences. History of the Uzbek language is more outstanding when its appearance and development is considered in direct connection with the history of the formation and development of this people. Without taking into account the historical laws of tribal and clan estates during the development of the Uzbek language, it is impossible to understand its distinct features, the totality of historically determined changes that have occurred not only in vocabulary, but also in the phonetic system, as well as partially in the grammatical structure of the Uzbek language.

\section{MATERIALS AND METHODS}

Therefore, the study of the Uzbek language at different phases of the historical development of the Uzbek people; the identification of its specific features in the grammatical and lexical structures; the formulation of the relationship between the written language and active spoken language, presented in the form of numerous subdialects and dialects; the definition of the dialect fundamentals assist to a more correct comprehension of the history of the Uzbek language as a whole.

\section{RESULTS AND DISCUSSIONS}

BARLAS - the ethnonym "barlos" has been known since the reign of Chingiz Khan. Rashididdin wrote that the four thousandth army that Chingiz Khan allocated to his son Chagatai consisted of Barlas, in particular, and that, like the Jalairs, they were originally a Mongol tribe called barulos, which means "thick, strong" in the Mongolian language. It also meant "commander, leader, brave warrior" and was correlated with the military courage of the tribe. In the 30-40s of XIII century Barlasesand Jalairs still had a Mongolian identity, then by the 60s-70s of XIV century both of them had already gone through the process of Turkization, primarily through the assimilation of Turkic dialects, as well as having entered into the process of mutual assimilation with the local Turkic population, Barlaswere concentrated in the territory of Kashkadarya region.

The Barlasessettled in the Kashkadaryaoas is in the first half of the XIVcentury. They began to spread to other regions during the period of Amir Temur, who, being of his origin from this tribe, provided them with patronage. It is known that even after his death, Barlasesoccupied an honorable position in the states of the Temurids. Thereby, some of them, after the defeat of his troops by the Dashti-Kipchak Uzbeks, went to India together with Babur.

IntheXVIcenturyBarlases lived on the left and right coast of the Amu Darya. By this time, this tribe had grown due to the accession of other tribes to it, since it was considered prestigious to enter into an alliance with it. However, in the future, after the establishment of the 
Sheibanids' power, the Barlases lost their positions. During the time of the Bukhara Khanate, a part of the Barlasescontinued to lead a semi-nomadic lifestyle and engage in livestock, preserving their name and traditional internal unity. This was manifested in the conclusion of marriages mainly between members of the tribe, as well as in the possession of a special eloquence, which served as a kind of "calling card" for members of the Barlastribe. Barlases in Shakhrisabz, which is located near the Samarkand region, on the contrary, believed that their ancestors had lived in Gissar for a long time, and then had returned to their native places - to the Kashkadarya oasis. Among the inhabitants of the village of YukoriTaragai (Kashkadarya), there is a legend that in the past they left these places and went to Gissar, from where they returned only at the beginning of the XIX century.

In the southern territories of Uzbekistan, two genera of Barlaseslived - oltibachcha and kalkhofiz. Oltibachcha, according to legend, came from six brothers. There are also different kinsand tribes, such as Kazibachcha, Pulatbachcha, Akhsakbachcha andNematbachcha. According to the zoning information in 926, 710 barlases were registered in Upper Kashkadarya, and they lived in the villages of Sayot, Khasantepa, Ommahon, Toshkalok, Ayokchi, Khonaka, and Taragai.

In these villages, tribes including, Tolibbachcha, Kazibachcha, Nematbachcha lived. Currently, ethnic names of Barlaseshave been preserved in Samarkand and Kashkadarya regions, but in other regions of Uzbekistan, the name barlos is found only in the form of an ethnotoponym, for example, the village of Barlas of the Sariosiyo district inSurkhandarya region. A small group of
Katagans in the village of Katagan in the Kashkadarya region calls themselves barlases, and their place of residence is called barlost. The Barlas dialect refers to the Karluk-Chigil dialect of the Uzbek language and, by many of its characteristics, stands close to the urban dialects of the Uzbek language.

DURMANS- one of the large and compactly living Uzbek clans. Some information about Durmans can be found in the works of many Russian and foreign travelers and researchers of the late XIX - early XX centuries. The opinion that the Uzbek-Durmanssettled in Central Asia during the colonization of Sheibani Khan were Mongolian tribes. This was one of the ethnic groups, which in the XV century participated in the election of Abdulkhair as an Uzbek khan in Dashti-Kipchak, later supported Sheybani Khan and settled with them on the territory of Maveraunnahr. A separate group of UzbekDurmanstook part in the conquest of Balkh and Kunduz as part of the troops of Sheibani Khan in Afghan Turkestan. It is mentioned that the first Uzbek ruler of Kunduz - Urusbek was from the Durmans. They tried to maintain their authority under the Ashtarkhanids dynasty.

At the beginning of the $X X$ century, UzbekDurmans lived in various places - in Balkh (Northern Afghanistan), Zarafshan, the upper basin of the Syrdarya and Khorezm. Durmans also lived separately in various settlements of the Zarafshan and Tashkent oases. For example, now on the territory of the Kibray district in the Tashkent region, there are such ethnotoponyms as the village of Durman, the garden of Durman. According to a comparative analysis of N. G. Borozna, who conducted special scientific studies of the material culture, economy and ethnographic characteristics of Durmans, the genomes of 
Durmans, like other Uzbek kins, are similar to the genomes of Kazakhs and Kyrgyz.

From the abovementioned, we can conclude that on the territory of Central Asia, Durmanswere also part of the Kazakhs, Kyrgyz and Turkmens, to some extent participating in the formation of these peoples. Their dialect belongs to the Kipchak dialect with the use of "dj".

KANGLI-as one of the many ancient ethnic groups, is part of the Uzbek, Karakalpak and Kazakh peoples. The ethnonym "Kangli" is mentioned in the Orhan Ghaziannals (VIII century) as "kengeress"; in the historical work of Constantine VII Flavius Porphyrogenitus (X century) under the name "kangars"; in the work of al-Idrisi (XII century) - "khankakishi". These and subsequent authors believed that the name "kangli" was derived from the name of a tribe or a union of tribes. According to $S$. G. Klyashtorny, these ethnonyms are directly related to China by the name "Kangyuy." However, it should be noted that the ethnonym "Kangyuy", indicated in the Chinese annals, means the name of an ancient state located in the lower reaches of the Syrdarya and Aral Sea regions. The ancestors of the Kangli were Saki, living on the banks of the Syrdarya. In the III century BC, they created the large state of Kang. In the II - I centuries $B C$ and I - II centuries AC, this state occupied a vast territory, including the Tashkent oasis, the southeastern territories of Kazakhstan, Maveraunnahr, Khorezm, the southern, southeastern and northwestern regions of the Aral Sea. During this period, as a result of the merging of the Saks with the Huns, Usuns and other Turkic peoples, a new people appeared the Kangars, who constituted the oldest indigenous Turkic layer formed in Central Asia. The Kangar culture appeared as a result of the combination of two cultures - a nomadic and semi-nomadic ethnic group (Huna, Usuna, etc.) with the culture of the local population (Saki). Archaeologists call this culture Kangyu culture. A significant part of the Kangars settled in the Tashkent oasis and Maveraunnahr.

Before the Mongol invasion, the Kangli, who entered into an alliance with the Kipchaks in the middle of the 11th century, lived in the steppes in the Irtysh region, in the territory from the lower reaches of the Syrdarya to the Dnieper. The Mongol invasion resulted in the movement of the Kangli group to the north, in the region of the Southern Urals, and assimilation with the Bashkirs. But a certain part of the Kangli continued to roam in the steppes of the Caspian and Aral Sea regions, and became part of the Kazakhs and Karakalpaks. Kangli, living on the banks of the Syrdarya, oases of Talas and Chu, became the settled population of the Khorezm oasis. Until the 17th century a large group of Kanglilived in Khorezm. In the following centuries, some of them were assimilated with the local population. But before the beginning of the 2oth century. a certain part of them retained their tribal identity. Mostly they lived in the volosts of Niyazbek, Toytepa and Okjar. At this time, the Kangli continued to lead a semisedentary lifestyle, engaged in agriculture and livestock. However, according to registration data in 1920, the presence of this ethnic group was not recorded in Kurama County. At the same time, the former names of the settlements that testify to the Kangli tribe living here in the past have been preserved. At the end of XVIII - beginning of XX century, the Kangli settled in Zarafshan, the current Gallaaral and Zaamin districts. The Kangli language contains elements of the KarlukChigil, Oguz and Kipchak dialects. For many centuries, the Kangli ethnic group maintained close ethnic and cultural contact with many 
ethnic groups (Kazakhs, Kyrgyz, Karakalpaks, Uzbeks). For this reason, a separate Kangli dialect was not recorded in linguistic studies. The groups that were part of the Uzbeks spoke Uzbek (Turkic) dialects, and those that were part of the Kazakhs and Kyrgyz spoke the corresponding languages.

KATAGANS - one of the large ethnic groups of the Uzbek people - Katagans - live in the Khorezm, Tashkent, Samarkand, Bukhara, Surkhandarya, Kashkadarya regions and in the Ferghana Valley of Uzbekistan. Katagans also live in Kazakhstan, Tajikistan and Afghanistan. Although the origin of the Uzbek-Katagans was not studied in a special study, information about this is common in various historical and ethnographic works. The first data on the Katagans are found in one of the historical and ethnographic works ofRashididdinFazlullohKazvini, "Jomieuttavorih", which was written in the XIV century. Much information is cited in the writings of other eastern historians, such as Abul Ghazi, Muhammad Yusuf Munshi, Mahmud ibn Vali.

Important information about the Katagans living in the Balkh region (Northern Afghanistan), which was their homeland, is contained in the writings of Burkhaniddin Khan Kushkeki. About the Katagansof the Zarafshan oasis, A.D. Grebenkin wrote. In the essays of N. A. Maev, written after the Gissar expedition of 1872 and 1878, there was a number of important information about the Katagansof the foothills of the Gissar Mountains. The works of Rashididdin and AbulGhazi contain legendary information about the origin of the Katagans, which say that the Uzbeks came from a woman named Alankuva from the Mongolian group of Nirun tribes. Although Rashididdin called the Katagans a Mongolian tribe, he noted that the Kataganswere not a Mongolian, but a Turkic tribe, which was only called the Mongolian. The ethnic history of the Katagans is quite complex, during the formation they were in close relations with many peoples of Central Asia - Kazakhs, Kyrgyz, Karakalpaks. For example, ChokanValikhanov, speaking of the Elder Zhuz of the Kazakhs, notes that from one of its branches the main genus of the Katagans originated, from the second Uysuns, from the third - Kangli. It relates these Katagans to the composition of the DashtiKipchak Uzbeks. At the beginning of the XVII century, they constituted the main support force of the ruler of Tashkent - Tursunkhan, and in the middle of the XVII century, one part became component of the Uzbek people, and the other part of the Kazakh tribe Chanishkli. Researchers attribute the emergence of the Katagans to the Uzbek people with the following tragic event: in 1628, the Kazakh Khan Ishim killed the ruler of Tashkent Tursun Khan, defeated and exterminated the Katagans, which were the main force of the latter. Part of the Katagans became part of the Kazakh Kangli tribe under the name Chanishkli, the rest fled to the south-west of the Syrdarya and joined the Uzbeks.

The written sources do not say that the Katagans were part of the Dashti-Kipchak Uzbek tribes who participated in the conquest of Maverannahr under the leadership of Sheibani Khan. But the sources have information that later, in the middle of the 16th century, they took their place as part of the Uzbeks as an authoritative class. According to historical data, in the 40 s of XVII century Katagans were one of the strong and unstable tribes living in Balkh and, partially, in Kunduz. This tribe is mentioned along with Aimaks, Khazars and others living in northern Afghanistan. 
KUNGRATS - were one of the Dashti-Kipchak Uzbek tribes. The area of their subsequent distribution includes the Surkhandarya, Kashkadarya and Khorezm regions of Uzbekistan. Legends about the origin of the Kungrats are found in the works of RashididdinFazlullohKazvini, "Jomieuttavorih". Many studies have suggested the Mongolian origin of the Kungrats. But B. Kh. Karmysheva writes in her studies: "It doesn't matter to us what the origin of the Kungrat is Mongolian or Turkic. Because different studies indicate that although certain ethnic groups are Mongolian tribes, before moving to Maveraunnahr at the beginning of the 16th century, they took a Turkic direction in language, culture and ethnic composition. "The Kungrats differed in status from other tribes because ChingizKhan and his relatives married the daughters of noble Kungrats, thereby elevating this tribe over others. According to I. P. Magidovich, the ancestors of most of the Khorezm Uzbeks were Kungrats who lived before the majority of the DashtiKipchak Uzbeks resettled.There are other assumptions about how the Kungrats settled in Uzbekistan.It is known that the epic of the Kungrat ethnic group "Alpamysh" reflects stories about the Kungrat people and their Baysun-Kungrat homeland. There are Karakalpak, Kazakh, Khorezm and Surkhan versions of this epic. The described events occur mainly in the Baysun-Kungrat region. Researchers say that Alpamysh was written a thousand years ago. If you take this point of view, then it can be concluded that some of the Kungrats lived on the territory of Maverannahr until the 15th century. A number of important information about the Kungrats is contained in many research works.According to the legends of the Kungrats themselves, the elder of their tribe was Kungirat-ata or Kungirbiy, who had four sons from his first wife: Vaktamgali,
Kushtamgali, Konzhigali and Ainni (Ainli). Sons are considered the founders of the Kungrat clan. Kungirat-ata had another fifth son, Tortuvli, whom he presented to his younger wife. Thus, Kungrats are divided into five genera, each of which is divided into several small genera.

The fact that there is a genetic link among the Karakalpak, Khorezm, Surkhandarya and KashkadaryaKungrats is confirmed by the identity of the genera in their composition. Some Kungrats of Sherabad (Surkhandarya region) believe that their ancestors moved from Khorezm, which complements the above. There is also a similarity in the genealogy of the Kungrats of Khorezm and Eastern Bukhara (i.e., the eastern part of the Bukhara Khanate). T.A. Zhdanko in his studies also pointed out that the genealogy of the Karakalpak and KhorezmKungratswas the same. Eight ethnonyms exactly coincide among the Kungrats of Eastern Bukhara, their Khorezm tribesmen, and all Karakalpak clans: Achamaili, Boltali, Bogazhel, Konjigali, Karakursak, Koshtamgali, Tortuvli and Tugiz (Togiz). Five ethnonyms of the Bukhara Kungrats and Uzbek-Kungrats of Khorezm are the same: Barak, Bobai, Zhilantamgali, Karabura, Nogai. The ethnonyms Aiinni, Akpichak, Baymokli, Kozokyoli, Kazak,Kaychili, Kanchi, Karabuyin, Karga, Kuldovli, Kopis, Kuyin, Kurama, Tarakli, Urus, Handakli, Chumichli, Irgakli, etc. coincide with the Karakalpaks. Thus, among the Kungirats of Eastern Bukhara 13 ethnonyms coincide with the KhorezmKungrats and 132 with the Karakalpak.

MANGITS - the term "mangit" in the sources is found as "mankit", "mankut". In the work of AbulGazikhan "Shazharai Turk" ("Tree of Turkic people"), a grandson of the khan named Mankitwas mentioned. T. Nafasov 
believes that the Mangits are one of the ancient Turkic tribes, a large ethnic unit that became part of the Uzbek people. The etymology of the word mangit is mang + atmingi. Mangat - the oldest name, the affix " $t$ " in Altai means collected. Although mangit and ming are the names of two tribes, they are identical in meaning and principle of creation. The definition is given according to the population. The transfer of ethnonyms to place names occurred in the XVII $-\mathrm{XIX}$ centuries.

There is information about Mangits in a number of ethnographic works. In this case, the sources mention that the ancestors of the Mangits were Mongolian tribes living in Mongolia at the beginning of the XIII century. During the XIII century, they settled in DashtiKipchak. In the XIII-XIV centuries, most of the Mangitssettled on the territory between the Volga and the Urals. During this time, under the influence of the Kipchaks, they forgot their language and adopted the TurkicKipchak dialect. At the end of the XIV century, they created their own separate state - the Mangits' Horde. In the middle of the XV century, the Mangits were called Nogai (Nugai), and their horde was called the Nogai Horde. In the middle of the XVI century, the Nogai Horde was divided into Big Nogai and Small Nogai. Subsequently, the Mangits from BigNogai entered the ethnic composition of the Uzbeks, Karakalpaks, and, in part, Kazakhs, and in the 16th century, they moved to the territory of Uzbekistan. Under the cultural influence of the local Turkic peoples, who had long lived in Maverannahr and engaged in agriculture, some of the Mangits gradually settled, another part of them in the late XIX - early XX centuries, led a seminomadic lifestyle, was engaged in livestock. At the beginning of the XVI century, during the movement of Sheibani Khan (grandson of the founder of the state of nomadic Uzbeks Abulkhair Khan) with Uzbek clans to the south, they included Mangits. About this, Muhammad Salih wrote: "There were many warriors, Haji Gogi was from a Mangit family. There were 4,000 Uzbeks, all relatives among themselves. Among them were the Kungirats, Mangits, Durmans, Ushuns and Uyrats. Mostly the Mangits settled in the Zarafshan Valley, partly in the Khorezm Khanate, the Karshi steppe, Chardzhou region on the left bank of the Amu Darya.The largest Mangit tribes were: oqmangit, tuqmangit, qoramangit, ochmangit, chalamangit, boygundimangit, temir-hadja, shobiy, gavlak, kusa, toz, karabayir, bakirchi, kula, tamgalimangit, kazakh, unikki, chukay, galabatyr, beshkal, chebakchik, uz, uvami. This dynasty ruled until 1920. As of 1924, more than 130 thousand Mangitpeople lived in Uzbekistan, of which about 100 thousand inhabited on the territory of the Bukhara emirate: 44 thousand- in the Bukhara oasis and in the Karshy district, 8 thousand- in the lower reaches of Zarafshan, 10 thousand in the middle reaches of Zarafshan, and 2 6ooin the Jizzakh district and in Khorezm - 10 thousand. In addition, in the Chardzhou district of Turkmenistan11 thousand Mangitslived.

Most of the Mangitsliving in the Karshi desert, Bukhara oasis, in the foothills and mountains of the Samarkand region were engaged in sheep livestock, and in the first two regions they bred Karakul sheep. The Mangits also engaged in agriculture. Their handicrafts were also slightly developed (carpet weaving, weaving of multi-colored fabrics, boz, alachi, kalami, etc.). The long-pile mangit carpet - the zhulhirs - was very famous. The Mangits spoke in the Kipchak dialect of the Uzbek language. But as a result of the merger with the population speaking the Karluk-Chigil dialect, in some places, the Mangits began to speak in 
mixed language, as evidenced by special studies.

UZBEKS - the ethnic name "Uzbek" is associated with the name of Uzbek Khan of the Golden Horde, who lived in the first half of the XIV century: "According to some researchers, the name Uzbek (as well as the ethnic name" Uzbek ") came from the name of the people "uz","oz", which were once called in Central Asia." First about the Uzbeks. In the VI-VII centuries, Uzbeks were part of the Western Turkic Kaganate, and in the VIII century, as part of the Khanate of Turks. In the 6os of VIII century., more precisely in 766, the Karluks, who subjugated most of the Uzbeks, occupied the Chu river basins. Since that time, the Karluks participated in the formation of the Uzbek clan.

Another part of the Uzbeks, who did not obey the Karluks, moved to the Syrdarya, mainly in the desert on the left bank. It was at this time (VIII century) on the shores of the Syrdarya and in the deserts in the southwest and north of the Aral Sea that the union of the Oghuz tribe (guz) was created. Later, in the 9th century, the Oghuz state was created. All the tribes living in this territory, including the ozs, were enslaved by the Oghuzes. A significant part of the bonds, which did not obey the Oghuzes, retreated and settled in the northwestern territory of the Aral Sea. Another part of the Uzbeks remained to live on the banks of the Syrdarya, separated from their fellow tribesmen who retreated to the west. Some groups of Uzbeks who remained to live on the banks of the Syrdarya began to lead a sedentary lifestyle, creating cities and large villages. They named some of them by their own name. For example, a city located between the left bank of the Syrdarya (between the city of Signak and the village of Barchinlikent) and in the west - the river Yaik
(Ural) was called Uzkend. It survived until the XIII century. Two mounds in the middle reaches of the Syrdarya are called IshkiUzkend and Kirgi-Uzkend and the lake is Uz. One of the cities located in the upper reaches of the Syrdarya (in the Fergana Valley) was called Uzkend (Uzgan) at the beginning of the Middle Ages. But in the XI century, people from the Azgish $(A z)$ tribe livedin Uzkend. Thereby, in the mountainous regions in the north of the Ferghana Valley, in the VIII-X centuries, (maybe even earlier) the ethnicity of the bonds had to live, subsequently moving on to a settled way of life. The bonds that moved to the northwestern territories of the Aral Sea in the middle of the 9th century located between the rivers. There lived the Kangli and Bizhanak tribes (Patzinaks), and in the northeast - the Kipchaks and Kimaks tribes. The Uzbeks strengthened and began to wage aggressive wars with surrounding tribes, especially with the Bizhanaks. Starting from these times, the Uzbek historians were mentioned by Greek historians Constantine VII Flavius Porphyrogenitus(X century), Attiliet (X century), Sclicy (XI century), Anna Komina(XII century) and other Uzbeks were also mentioned in the works of Mashudi ( $X$ century) and the Armenian historian Matthew of Edessa (XI century). Constantine VII Flavius Porphyrogenituswrote: "Only the Uzs(Uzbeks) could fight the Patzinaks; they went with large troops to the war with the Khazars". At the beginning of the X century. Uzbeks owned a large territory on the middle reaches of the current Volga River, but did not dominate here for long. In the middle of the $X$ century. Kipchaks who lived in the foothills of the Ural Mountains began to make regular raids. Most of the Uzbeks, unable to withstand the onslaught of the Kipchaks, went to the deserts and settled on the lands along the left bank of the Don. The right bank belonged to the Khazars. Don was the border 
between them. At the end of the $X$ - the first half of the XI century, the Uzsagain attacked the Bizhanaks who lived between the Dnieper and the Don, and in 1043 occupied a significant part of the land in the east of the Dnieper. The bonds encroached on the territory belonging to the Russian princes. In alliance with the Kipchaks, Russian princes opposed the Uzbeks. The uzsUzsunder their onslaught in 1064 crossed the Danube into the territory of the Greek Empire. According to some reports, 600 thousand Uzscrossed the Danube River. For a short period of time, part of them was enslaved by the Greek emperor Alexei. Warriors began to serve in the Greek troops, they were allocated land for living. Another part of the Uzsdid not obey the local administration and, having settled in the northern regions of the Greek Empire, continued offensive operations. After long fights in the $80 \mathrm{~s}$ of IX century they nevertheless submitted to the Greek Empire. Subsequently, Uzsscattered across the territories of several states on the banks of the Danube, mixed with the local population and forgot their ethnic name. It is possible that the Gagauz (in fact, "uguzguz"), who live in Moldova, Romania, Hungary and the Balkan Mountains, are direct descendants of those same Uzbeks. In the X-XI centuries, some groups of Uzbeks moved to the territory of Asia Minor and became part of the local Turkic peoples. In the archival materials of the Usmonli empire (XVI-XVIII centuries), the ethnonym Karauz is found. It is interesting that in the middle reaches of the Zarafshan River, mainly in the Payaryk region, one of the Uzbek groups is called "karauz". This example, of course, testifies to the fact that the first ancestors of the Karauz people, which are part of the Karauz and Uzbeks who settled in Turkey, are one people (part of the Uzs). Subsequently, during centuries-old historical events, the Karauzes spread and became part of several Turkic peoples, including the Uzbeks and Ottoman Turks. Their relatives, most of the aforementioned Gagauz, now live in Moldova. Only one part of the Uzsmoved to Western Europe. Significantly more of them lived in the southern Russian steppes. In the second half of the XI - the first half of the XIII centuries, the Kipchaks who lived in this territory also included Uzs. During the time of the Mongols (XIII-XIV centuries), a significant part of the Kipchaks moved to the deserts of the left bank of the Volga, and then to the DashtiKipchak steppe. Since that time, a significant part of the Uzsbecame part of the Kipchaks. In the deserts adjacent to the middle reaches of the Syr Darya, at the beginning of the Middle Ages, nomadic livestock breeders lived, among them there were Uzs, the next generations of which survived until the 16th 17th centuries. In the middle of the XVIII century, they migrated to the northern slopes of the Nurata Mountains. Some groups of Uzs, in which the number of decreased, settled in the Zarafshan oasis and took up farming. A part of the livestock breeding Uzsmoved to the Karshi steppe and continued their traditional livestock breeding. The Uzsliving in the Karshi steppe and the Zarafshan oasis are mentioned in the letters of the Bukhara Khan Amir Khaidar (1800-1826) and the list of 92 Uzbek tribes compiled in the 19th century. At the beginning of the XX century. Uzsare also registered as part of the Lakay Uzbeks living in Tajikistan. The bulk of Uzsstill lives on the territory of Uzbekistan and has retained its ethnic name (Uzs). They are mainly located in the villages of Kharduri, Taloktepa, Surabozor, Utamali, Khushakholi, Mailidzhar and other villages of the Karshi steppe. Some groups of Uzslive in the territory of Navoi region and the economy of Ulus Kattakurgan region. The ethnic group $\mathrm{Az}$ was actively involved in the formation of the Uzbek people. Their 
ancestors lived in the foothills of the Altai and Sayan mountains, on the Tuva territory and were part of the tribal union of the body. In 709, one of the Turkic khans Magilan seized the lands of the Azs, and in 716 his brother Kultegin dealt them a crushing blow. After this, the ethnic group Azs lost their independence and they were divided into several groups. One group left its territory and settled in the Chui valley. These Azs are also mentioned in the works of Ibn Khurdodbeka and Gardizi (11th century). According to the information provided in the sources, the Azs settled in the Chui valley were included in the tribal union of turgesh. V.V. Bartold attributes the Azs to the Azgish, which are a branch of the Turgeshev. In 766, the Karluks occupied the area of Jeti-suu, including the Chui river valley. Some of the Azs obeyed the Karluks and remained on these lands; the other part moved to the lower Syrdarya, a desert near the Aral Sea. As we mentioned above, a significant group of people lived in the city of Uzkend (Uzgan) and its environs. One of the groups of Azs remained in its ancient homeland - in the foothills of the Altai and Sayan mountains. Under the names of az, tertas (turt-az), dueti-az (ettiaz), they are still preserved in the structure of such Altai peoples as Altai-KizhiTeleuts, telly and other Turkic ethnic groups of this region. The term az (and in the form of oz, uz) is found in the names of the localities and rivers of Altai and the Yenisei. As mentioned in the history of the state of Yuan - Yanshi, created in the XIII century. Mongols in the north of the Kyan River (KemEnasay), in it was an area called Us. Ethnicity $\mathrm{Az}(\mathrm{Oz}$, az-saray) has survived to this day and lives in the Samarkand and Kashkadarya regions, retaining its ethnic name. Based on all the above data, it can be argued that $\mathrm{Uz}$ and $\mathrm{Az}(\mathrm{oz})$ are the ethnic name of two different tribes, the remains of which have survived to this day.
YUTHS (ZHUZS) is one of the largest Uzbek tribes. At the end of XIX - beginning of XX century, they lived compactly in two places: theGissarYuths lived inSurkhan and the Gissar Valley, the UratepinianYuths inhabitedin the steppes from Zarafshan to the Syrdarya. According to $X$. Daniyarov, the Yuthsare considered the largest and most numerous clan among 92 Uzbek tribes and clans. Perhaps the authority of the Yuthsamong the people increased after many members of the Ming, another large Uzbek tribe, urbanized and forgot their tribal origin. Surkhandarya Turkmen Yuthshave 16 genera and are divided into two large groups: zhilontamgali and vokhtamgali. The question of the origin of groups of the genus Yuths(zhuzs) is rather complicated. The date of their relocation to Hisar is not known. Different groups of Yuths, such as Mark, Korabchi and Turkmen Yuths, did not settle in Gissar at the same time. In Jizzakh and its around, to some extent they maintained family relations with the Kazakhs in terms of dialect and culture.

\section{REFERENCES}

1. Rashididdin, Collection of Chronicles, Moscow.; L., 1952. Volume 1, Book 1. Page 257.3

2. Yakubovsky A. Y. On the ethnogenesis of the Uzbek people. Tashkent, 1941. Zaheriddin Muhammad Babur. Baburname. Tashkent, 1960. page. 232-236. 320

3. Ivanov P.P. Essays on the history of Central Asia (XVI - mid-XIX century). M., 1958. P. 102, 103. 2 Materials on the zoning of Central Asia. Tashkent, 1926. Prince. 1.1.4 P. 200. Kubakov K. About some tribal groups of Uzbeks of Upper Kashkadarya (second half of the 19th beginning of the 2oth centuries) // Ethnographic study of life and culture 
of the Uzbeks. Tashkent, 1972. 4 Dzhuraev T. Uzbek dialects of Upper Kashkadarya. Tashkent, 1969.P. 74.5

4. Ivanov P.P. Essays on the history of Central Asia (XVI - mid-XIX century). M., 1958. Page. 102, 103. 2 Materials on the zoning of Central Asia. Tashkent, 1926. Book. 1.1.4 Page. 200. Kubakov K. About some tribal groups of Uzbeks of Upper Kashkadarya (second half of the 19th - beginning of the 2oth centuries) // Ethnographic study of life and culture of the Uzbeks. Tashkent, 1972. 4 Dzhuraev T. Uzbek dialects of Upper Kashkadarya. Tashkent, 1969.Page. 74.5

5. Materials on zoning of Central Asia. Book 2. The territory and population of Bukhara and Khorezm. Part 2. Khorezm. Tashkent, 1926. Page. 24, 29. 2 See: A. Semenov. On the origin and composition of Sheibanikhan Uzbeks // Materials on the history of Tajiks and Uzbeks of Central Asia. Vol. I. TIIAE AN Tajik SSR. 1954.Volume. 12.Page. 115. 3 See: BartoldV. B. The ceremony at the court of the Uzbek khans in the XVII century. // M., 1964. T. 2. Part 2. Page. 207. 'See: Karmyshen V. X. Essays on the ethnic history of the southern regions of Tajikistan and Uzbekistan. M., 1976. page. 107-108. " See: Borozna N. G. Material culture of Uzbeks of the Babataga and valleys // Material culture of the peoples of Central Asia and Kazakhstan. M., 1966;

6. Khoroshkhin A.P. Collection of articles relating to the Turkestan Territory. SPb., 1876. Page. 165. 2 See: Materials of the All-Russian Census ... P. 115. 3 See: Materials on regionalization of Uzbekistan. Vol. 2. Kokand District. Samarkand, 1926. Page. 18, 19, 23. 4 See: Materials on the zoning of Central
Asia. Volume 2. Part 2. Tashkent, 1926.page. 99. 5 See: Zhdanko T.A. Essays on historical ethnography of Karakalpaks. M .; L., 1956. 6 See: K. Shaniyazov. The State of Kang and Kangli. Tashkent, 1990. Page. 142. 325 EthnicAtlasofUzbekistan

7. Nafasov T. Explanatory Dictionary of Toponyms of Uzbekistan. Tashkent, 1968.page. 113-114. 2 See: Materials on zoning of Central Asia. Prince 1. Part 12. Tashkent, 1926. Kubakov K. The ethnic composition of the rural population of Upper Kashkadarya in the late XIX - early XX century. Tashkent, 1973. Gubaeva S. S. Population of the Ferghana Valley in the late XIX - early XX centuries. (Ethnocultural processes). Tashkent, 1991. 3 Muhammad Salih. Shaybaniname. Tashkent, 1989. page. 197. 331 Ethnic Atlas of Uzbekistan. 